\title{
Mutation in Sos1 dominantly enhances a weak allele of the EGFR, demonstrating a requirement for Sos1 in EGFR signaling and development
}

\author{
Dennis Z.M. Wang, ${ }^{1}$ Vicki E. Hammond, ${ }^{2}$ Helen E. Abud, ${ }^{1}$ Ivan Bertoncello, ${ }^{1}$ John W. McAvoy, ${ }^{3}$ \\ and David D.L. Bowtell ${ }^{1,4}$ \\ ${ }^{1}$ Trescowthick Research Laboratories, Peter MacCallum Cancer Institute, East Melbourne, Victoria, Australia 3002; ${ }^{2}$ The \\ Howard Florey Institute of Experimental Physiology and Medicine, University of Melbourne, Parkville, Victoria, Australia \\ $3052 ;{ }^{3}$ Department of Anatomy and Histology and Institute for Biomedical Research, University of Sydney, Sydney, NSW, \\ Australia 2006
}

We have investigated the role of the mammalian Son of sevenless 1 (Sos1) protein in growth factor signaling in vivo by generating mice and cell lines that lacked the Sos1 protein. Homozygous null embryos were smaller than normal, died mid-gestation with cardiovascular and yolk sac defects, and their fibroblasts showed reduced mitogen-activated protein kinase activation in response to epidermal growth factor (EGF). An intercross of mice mutant for Sos1 and the EGF receptor (EGFR) demonstrated that a heterozygous mutation in Sos1 dominantly enhanced the phenotype of a weak allele of the EGFR allele (wa-2). These animals had distinctive eye defects that closely resembled those seen in mice that were null for the EGFR or its ligand, TGF $\alpha$. Our findings provide the first demonstration of a functional requirement for Sos 1 in growth factor signaling in vivo. They also show that the genetic test of enhancement of weak receptor allele by heterozygous mutation in one component represents a powerful tool for analyzing the ras pathway in mammals.

[Key Words: Son of sevenless; EGF receptor; protein tyrosine kinase receptor signaling ras; gene targeting]

Received September 27, 1996; revised version accepted December 17, 1996.

Son of sevenless (Sos) proteins are guanine nucleotide exchange factors (GEFs) that catalyze the activation of ras proteins by facilitating GDP-GTP exchange. Humans and mice each have two unlinked Sos genes (Sos1, Sos2), both of which are widely expressed in adult tissues and cell lines (Bowtell et al. 1992; Chardin et al. 1993; Webb et al. 1993). The mouse and human Sos1 proteins promote guanine nucleotide exchange on $\mathrm{H}$-ras and $\mathrm{K}$ ras (Buday and Downward 1993; Liu et al. 1993; Nakanishi et al. 1994; Porfiri et al. 1994) but not on ras-related proteins, such as Rap1, RhoA, or Racl. Human Sosl shows markedly more exchange activity on prenylated, compared with unmodified, H- and K-ras substrates (Porfiri et al. 1994). Ras proteins are expressed and required in most, if not all, mammalian cells (Marshall 1995). However, the contribution that Sos proteins make to ras activation in vivo, relative to other GEFs, is unclear and the question of which GEFs are the major activators of ras remains unresolved. Relatively few other mammalian ras GEFs have been described and their roles do not

${ }^{4}$ Corresponding author.

E-MAIL dbowtell@petermac.unimelb.edu.au; FAX 61-3-9656-1411. appear to overlap substantially with Sos (for review, see Bowtell 1996a).

Extensive biochemical studies implicate Sos proteins in signaling by a number of mammalian tyrosine kinase receptors, including the insulin, epidermal growth factor (EGF), and nerve growth factor (NGF) receptors (for review, see Bowtell 1996a). Sos1 frequently forms complexes with activated receptors, or other proteins such as Shc, following the stimulation of cells with growth factors. In these circumstances Sosl is often phosphorylated on serine and threonine residues. Although such events suggest Sos proteins are directly involved in signaling by growth factors, their functional role in these situations remains largely untested. A dominant negative Sos 1 protein has been generated by deletion of the catalytic domain and has been used to block the activity of endogenous Sos 1 protein in Chinese hamster ovary (CHO) cells (Sakaue et al. 1995). Ras activation in response to insulin is attenuated in cells that highly overexpress this dominant negative protein. However, it unclear whether this protein is a specific antagonist for Sosl or whether, for example, it also blocks the activity of Sos2. The ubiquitous expression of Sos proteins in cell 
lines has complicated a structure-function analysis of these proteins. As a result such studies have relied on the overexpression of Sos proteins and have assayed Sos function by measuring either a constitutive elevation in GTP-bound ras in transfected cells (McCollam et al. 1995) or cell transformation (Wang et al. 1995). These experiments have not addressed the role of individual domains of Sos proteins in signaling by specific growth factors.

In contrast to the mammalian proteins, a functional requirement for the Drosophila Sos protein (D-Sos) in signaling by a number of receptors is well established. Significantly, this understanding has been achieved despite the fact that a homozygous mutation in $D$-Sos results in pleotropic defects and early embryonic lethality (Rogge et al. 1991; Simon et al. 1991). The discovery of D-Sos, and recognition that it is essential for signaling by receptors such as sevenless, torso, and Drosophila EGF receptor (DER), required a specific type of genetic analysis. This analysis used receptor alleles that are particularly sensitive to a halving of the gene dosage of $D$-Sos (Rogge et al. 1991; Simon et al. 1991; Doyle and Bishop 1993). For example, a heterozygous $D$-Sos mutation enhances (exacerbates) the phenotype of a partially functional sevenless allele and suppresses the phenotype of a weakly dominant $D E R$ allele. Both findings demonstrate that the D-Sos protein is positively required for signaling by these tyrosine kinase receptors. This approach is powerful because the requirement for $\mathrm{D}$-Sos in signaling can be investigated without the problems of lethality and pleotropy that arise in homozygous mutants.

To better understand the role of the Sos 1 and Sos2 proteins in mammalian growth factor signaling we have commenced a genetic analysis of these proteins. Here we describe the targeted disruption of the Sos 1 gene and its consequences for signaling by EGF. We found defective mitogen-activated protein (MAP) kinase (MAPK) activation in response to EGF in homozygous mutant (Sos1-/-) cells and a strong genetic interaction between a heterozygous Sos1 mutation and weak allele of the EGF receptor (EGFR) (wa-2). These findings demonstrated a specific requirement for the Sosl protein in EGF receptor signaling and establish the utility of a valuable genetic assay for evaluating signaling molecules in mice.

\section{Results}

Targeting of the Sos1 locus

In order to determine the extent of Sos gene expression we performed Northern analysis of Sos1 and Sos2 RNA in tissues and cells. Both Sos1 and Sos2 were found to be widely expressed (Fig. 1A). The Sos1 gene expresses at least two transcripts in all tissues and cell lines examined, including embryonic stem (ES) cells. Western blot and cDNA analyses indicated, however, that only one Sos 1 protein was produced (data not shown). Sos2 showed a less extensive pattern of expression compared with Sos 1 and was not detected in ES cells. We chose to mutate Sos 1 initially as it is more widely expressed than
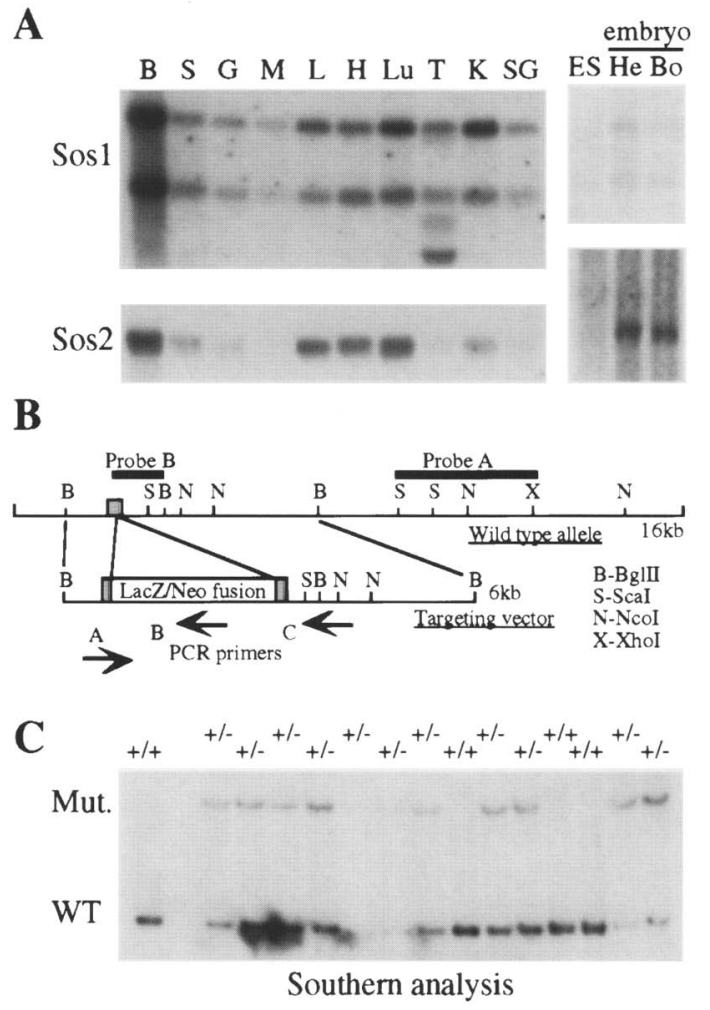

Figure 1. Expression of $S o s$ genes and targeted disruption of the Sos1 locus. (A) Northern analysis of Sos 1 and Sos 2 expression in adult tissues and ES cells. Sos1 expression was detected in all tissues, as well as in ES cells and E13 embryonic heads ( $\mathrm{He}$ ) and bodies (Bo). Sos 2 expression tended to be more variable than Sos1 and was not detected in ES cells. Approximately three times more brain RNA was loaded compared with other tissues, accounting for the apparently stronger expression of Sos 1 in the brain. (B) brain; (S) spleen; (G) small intestine; (M) skeletal muscle; (L) liver; $(\mathrm{H})$ heart; (Lu) lung; $(\mathrm{T})$ testes; $(\mathrm{K})$ kidney; (SG) salivary gland. $(B)$ Schematic representation of the genomic DNA surrounding the second coding exon (box) of the murine Sos1 locus. A lacZ-neo selectable marker was introduced into this exon and electroporated into ES cells. Probe A was used to initially detect mutant ES cell clones. Subsequent Southern analysis of mutant mice and cell lines used Probe B (see Materials and Methods). (C) Typical results obtained from a Southern analysis of $B g I I I-$ digested tail DNA from the litters of a heterozygous intercross of Sos $1+1-$ mice. Note only heterozygous or wild-type mice were obtained.

Sos2 and as most of the biochemical data relates to the Sos1 protein rather than Sos2 (Bowtell 1996a).

The Sos1 gene was mutated in murine ES cells by homologous integration of a lacZ-neor ${ }^{r}$ cassette, which was placed in frame with the Sos 1 coding sequence (Fig. 1B). Integration of this construct into the Sos1 locus should create a fused protein of the first 44 amino acids of Sos1, $\beta$-galactosidase, and neomycin phosphotransferase, expressed under the control of the Sos1 promoter. This targeting strategy took advantage of the high level of enrichment for homologous recombination events obtained with constructs in which the selectable marker 
lacks a promoter and translational initiator (Rossant 1993). In addition, the vector also provided an in vivo single cell marker ( $\beta$-galactosidase) of Sos 1 expression. The targeting event was predicted to result in deletion of $97 \%$ of the Sos 1 protein and was expected to generate a null allele, as a more carboxy-terminal truncation of $D$ Sos (amino acid 412) completely inactivated the protein (Simon et al. 1991).

The construct was introduced into R1 ES cells (Nagy et al. 1993) and a targeted ES cell clone obtained (see Materials and Methods). Several of the chimeric animals produced with this clone transmitted the targeted allele through their germ line, resulting in heterozygous $\mathrm{Fl}$ animals with either $129 \mathrm{~Sv} \times \mathrm{C} 57 \mathrm{BL} / 6 \mathrm{~J}$ or $129 \mathrm{~Sv}$ genetic backgrounds. Adult heterozygous mice $(\operatorname{Sos} 1+\mid-)$ were of normal size, appearance, fecundity, and longevity (data not shown). Heterozygous $F_{1}$ animals were intercrossed to produce mice that were homozygous for a mutation in Sos1. Tail DNA from the resulting $F_{2}$ pups was analyzed by Southern blotting (Fig. 1C). No homozygous mutant pups were obtained from a total of 317 animals analyzed (Table 1). The ratio of wild-type to heterozygous pups obtained was consistent with the death of homozygous Sos1 mutant embryos in utero.

\section{Loss of Sosl results in mid-gestational lethality}

To determine the point at which Sos1-/- animals died, we developed a PCR-based assay to genotype embryos throughout gestation (Fig. 2A). The latest time at which intact homozygous mutant embryos could be found was embryonic day 12 (E12) (Table 1). PCR analysis of embryos collected from E9 to E11 showed the expected Mendelian distribution of genotypes, indicating that homozygous mutant embryos were not being lost prior to this stage. Western blot analysis was performed on geno-

Table 1. Frequency of genotypes in offspring of heterozygous intercrosses of Sos $1+/-$ mice

\begin{tabular}{lccc}
\hline & \multicolumn{3}{c}{ Genotype } \\
\cline { 2 - 4 } Animals & $+/+$ & $+/-$ & $-/-$ \\
\hline Live born & & & \\
$\quad$ 129Sv $\times$ C57BL/6) & 74 & 141 & 0 \\
$\quad$ 129Sv & 30 & 62 & 0 \\
Embryos & & & \\
E9 & 20 & 35 & 20 \\
E10 & 23 & 56 & $25(15)$ \\
E11 & 18 & 21 & $14(10)$ \\
E12 & 5 & 10 & $4(4)$ \\
E14-18 & 4 & 14 & $6(\mathrm{R})$ \\
\hline
\end{tabular}

Animals of each genotype are indicated. Numbers in parenthesis indicate number of embryos that were grossly abnormal (pale yolk sac, hemorrhage and/or distended heart). (R) Embryos had degenerated and were being resorbed.

${ }^{a}$ All data obtained from $129 \mathrm{~Sv} \times \mathrm{C} 57 \mathrm{BL} / 6 \mathrm{~J}$ background animals. bAdditional focal resorption sites, seen in other late gestation pregnancies, could not be genotyped reliably and these pregnancies are not included.

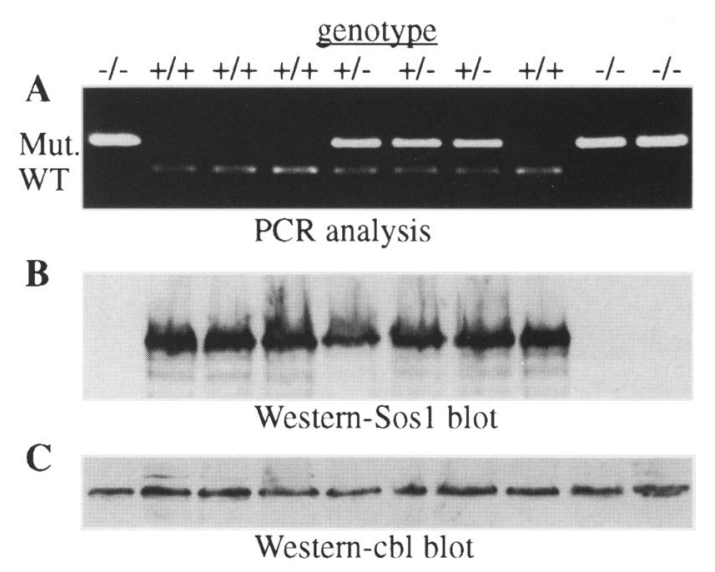

Figure 2. Sosl protein expression in mutant mice. $(A) \mathrm{Em}$ bryos isolated mid-gestation and genotyped using a PCR-based technique, which produced diagnostic fragments of $200 \mathrm{bp}$ (wild type) and $400 \mathrm{bp}$ (mutant). (B) Sos1 protein expression assayed by immunoblot with a carboxy-terminally directed Sos 1 specific antiserum. Expression of the protein was reduced in heterozygotes and undetectable in homozygotes. $(C)$ Control for the amount of protein loaded by immunoblot of the same lysates with an antisera directed to the C-cbl protein.

typed embryos using a Sos1-specific antiserum, to confirm that targeting of the Sos1 locus had eliminated expression of full-length Sos1 protein. As anticipated, Sos1-/ - animals completely lacked detectable Sos1 protein (Fig. 2B). Expression of Sos 1 in heterozygotes was approximately half that of wild-type litter mates when the amount of protein was normalized by probing with a control antibody (Fig. 2C; data not shown). We found no evidence of a compensatory up-regulation of Sos 2 expression in Sos 1+/- or Sos 1-/- embryos when tissue extracts were probed with a Sos2-specific antiserum /data not shown).

\section{Sos1-/-embryos have cardiovascular abnormalities}

The Sos 1-/ - embryos displayed a range of defects at midgestation. From E9 onward homozygous mutant embryos were obtained that were generally smaller than their heterozygous or wild-type littermates. Mutant embryos frequently had an enlarged heart and distended pericardium, compared with littermate controls (Fig. $3 \mathrm{~A}-\mathrm{C})$. The major vessels in these animals were also distended and there were areas of extensive hemorrhage (Fig. 3C; data not shown). In addition, the yolk sacs of the Sos 1-/- animals were pale compared with controls (Fig. $3 \mathrm{D}, \mathrm{E})$. Other defects observed occasionally in the Sos 1-/ - embryos included gross malformation of the mid-brain region and cleft palate (data not shown). Although no grossly normal Sos 1-/- embryos were identified after E12, apparently normal homozygous mutant embryos were seen as late as E11 and obviously malformed embryos observed as early as E9 (Table 1). One possible explanation for the variation observed is the influence of modifier genes that segregate unequally be- 


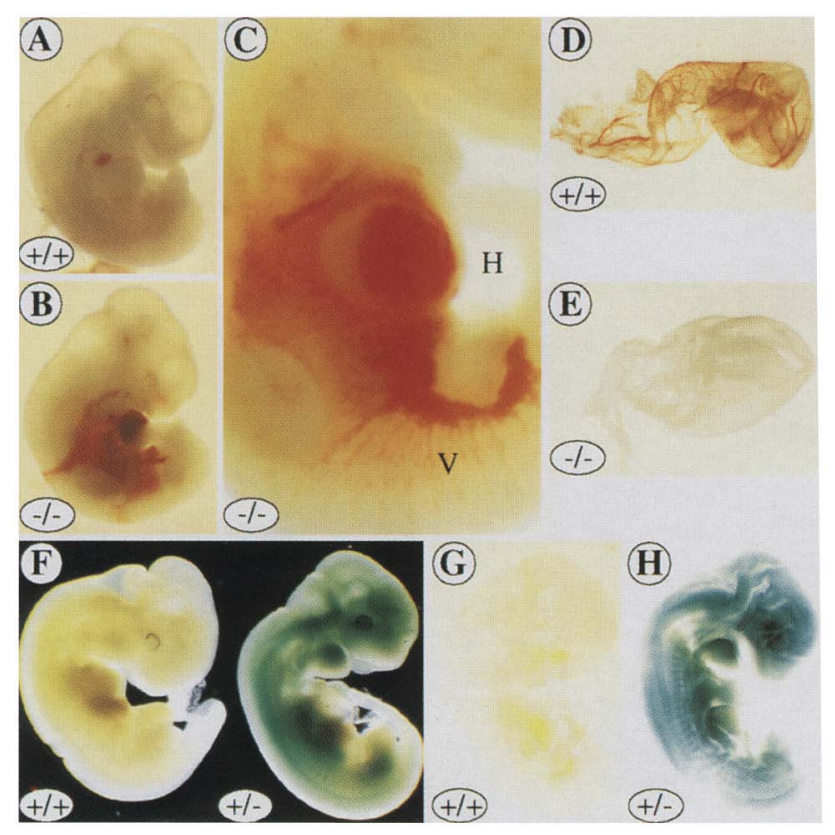

Figure 3. Gross morphology of Sos 1-/- embryos and $\beta$-galactosidase staining of Sos $1+/-$ embryos. (A) Normal wild-type E11.5 embryo and $(B)$ Sos1-/- littermate with cardiovascular defects. $(C)$ Enlarged region of $B$, showing distension of the heart and dilation of the major vessels. $(\mathrm{V})$ distended vessels; $(\mathrm{H})$ adjacent heart. $(D)$ Yolk sac of a wild-type E11.5 embryo and $(E)$ Sos1-/ - littermate. Vascularization of the wild-type yolk sac was obvious compared with the Sos $1-/-$ yolk sac. $(F)$ Uniform $\beta$-galactosidase expression was seen in whole-mount E11.5 Sos 1+/ - embryos, but not in the wild-type littermate, Sos 1+/+. $(G, H)$ Sagittal sections of the animals shown in $F$.

tween mixed 129Sv $\times$ C57BL/6I background embryos. Indeed, our initial findings indicated that embryos with a uniform 129Sv genetic background were more severely, and more often, affected at E9 than embryos from $129 \mathrm{~Sv} \times \mathrm{C} 57 \mathrm{BL} / 6 \mathrm{~J} \mathrm{F1}$ heterozygous parents $(\mathrm{H}$. Abud, D. Wang, and D. Bowtell, unpubl.).

Interpretation of mutant phenotypes is often facilitated by knowledge of the pattern of expression of the targeted gene. The Sos 1 targeting construct incorporated a lacZ marker, in frame with the Sos 1 coding sequence and expressed under the control of the Sos 1 promoter. As a result, the expression of $\beta$-galactosidase in heterozygous embryos should reflect the expression of Sos1. When mid-gestational heterozygous Sos 1 embryos were stained with X-gal we found a widespread low level of $\beta$-galactosidase activity in developing tissues (Fig. 3F-H; data not shown). Unfortunately, this pattern, the first description of Sos1 expression during mouse development, was not particularly useful in identifying sites where Sos 1 protein may be specifically required. It was, however, consistent with Sos1 being a major activator of the widely expressed ras proteins.

Histological analysis of Sos 1-/- mice revealed a number of defects that were consistent with the gross morphological features seen in mutant embryos. The myo- cardium of mutant embryos frequently showed reduced trabeculation and the ventricles and atria were often congested with blood (Fig. 4A-F). Our initial findings indicate that the orientation of the heart during development may also be abnormal in Sos1-/- mice (Fig. 4, cf. $\mathrm{A}$ and $\mathrm{B}$ ). The heterogeneity observed in the gross mutant morphology of embryos was also reflected in the severity of cardiac defects observed histologically (e.g., see Fig. 4E, F). Other aspects of cardiac development appeared relatively normal, including the partitioning of the heart and the development of endocardial cuffs (Fig. $4 C, D)$. The major vessels of mutant embryos were congested compared with controls (Fig. 4, cf. G and H) and there were focal areas of hemorrhage associated with these vessels (Fig. 4G). More extensive extravasation of nucleated red cells into tissue spaces was seen in embryos that were clearly degenerating (data not shown). Whether this was a secondary consequence of the advanced degree of degeneration of these embryos or a primary defect was unclear. Examination of the yolk sacs from Sos1-/- embryos showed that although they were severely depleted of nucleated red cells, they appeared otherwise normal (data not shown). The trophoblast giant cell, spongiotrophoblast, and labyrinthine trophoblast layers in the placentas from homozygous mutant embryos were comparable to their littermate controls (data not shown), indicative of normal placental development in Sos1-/- mice.

\section{Analysis of Sos1-/- fibroblasts, ES cells, and hemopoietic progenitors}

Ras proteins regulate a serine threonine kinase cascade involving raf, MAPK kinase (MEK), and MAPK that controls cell proliferation and differentiation. As Sos proteins are believed to be important activators of ras, we investigated the proliferative and differentiative capacity of isolated Sos1-/- cells. For these studies we derived Sos1-/- ES cells by selection of a heterozygous clone in increased concentrations of G418 (Mortensen et al. 1992). These cells were of particular interest as ES cells do not express Sos2 (Fig. 1A), which, if present, might compensate for the loss of Sos1. We found no difference, however, between Sos1-/- ES cells and the parental clone in either their proliferative capacity or in their ability to differentiate into hemopoietic cells when plated in methyl cellulose (D. Wang, A. Elefanty, and D. Bowtell, unpubl.). To further characterize the differentiative capacity of isolated Sos1-/- cells, we cultured dispersed yolk sacs from E9 Sos1-/- embryos and their littermates, under conditions allowing the formation of myeloid colonies. No difference was observed in the number or size of colonies obtained from wild-type, heterozygous, or homozygous mutant yolk sacs (data not shown).

Sos 1 has been shown to inducibly associate with the EGFR, following EGF stimulation (Buday and Downward 1993; Egan et al. 1993; Rozakis-Adcock et al. 1993) and D-Sos is required for signaling by the Drosophila EGFR homolog (Rogge et al. 1991; Simon et al. 1991). We 

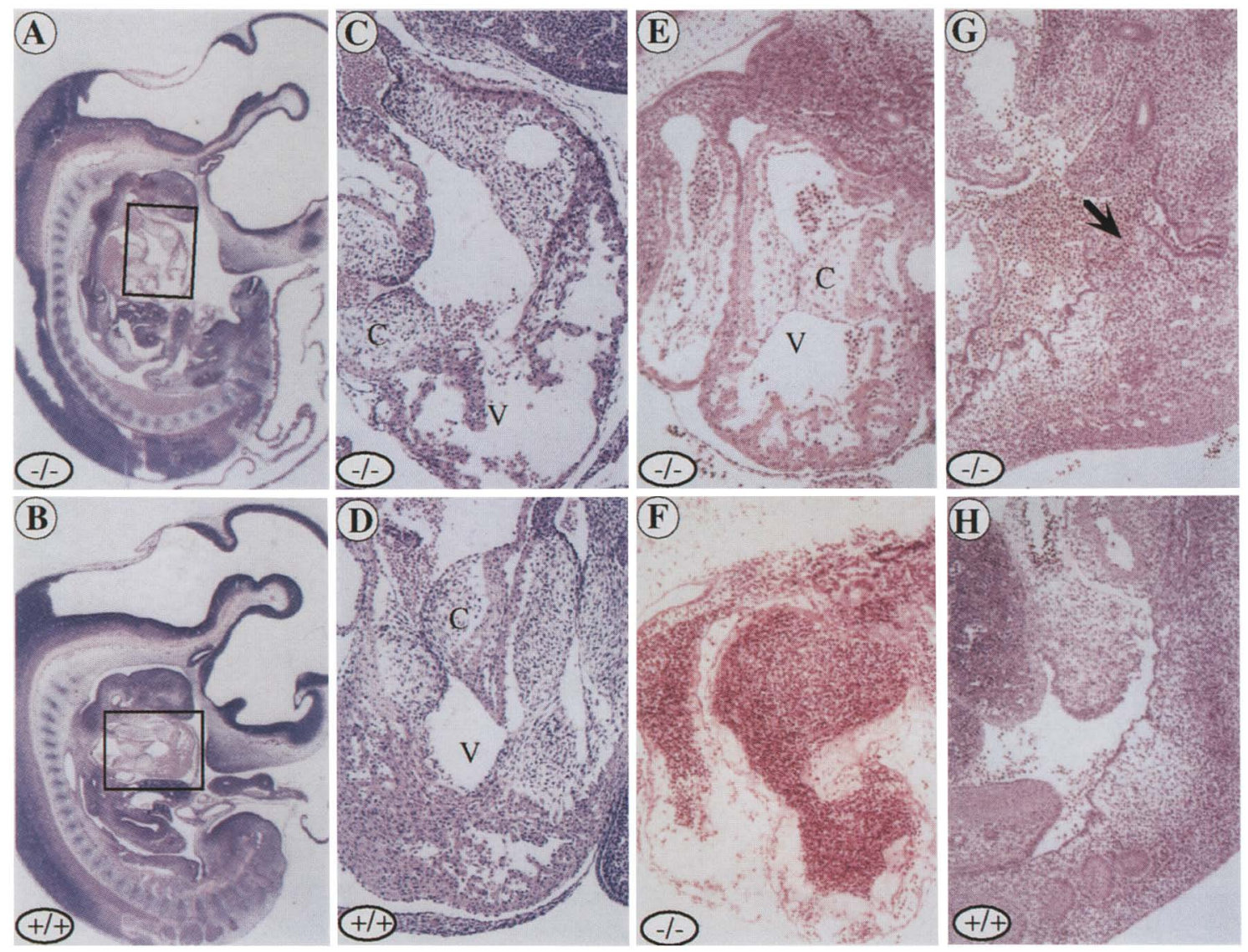

Figure 4. Histological analysis of Sos 1 mutant mice. $(A, B)$ Sections through a Sos $1-\mid-(A)$ and wild-type $(B)$ littermate E11.5 embryos. Boxed regions are shown in greater detail in $C, D$. $(C)$ Defective myocardial development in a Sos1-/- embryo. The wall of the ventricle $(V)$ was thin and poorly trabeculated compared with its littermate $(D)$. Development of other structures, such as endocardial cuffs $|C|$, appeared normal. However, the position of the heart in the Sos1-/-embryo may be abnormal. (E,F) Sections through E10.5 Sos1-/embryonic hearts, showing the range of severity of this cardiac phenotype. Whereas the heart shown in $E$ appeared near normal, the heart shown in $F$ appeared to be degenerating and both the atrium and ventricle was congested with blood. $(G, H)$ Sections through a Sos 1- $/-(G)$ and wild-type $H$ littermate E10.5 embryos. The animal shown in $G$ appeared grossly hemorrhagic. Major vessels were distended with nucleated red cells and an area of focal hemorrhage into the tissues is indicated (arrow). $(H)$ Corresponding region of a littermate control embryo.

were therefore interested to see how the absence of Sosl influenced signaling downstream of the EGFR. For these experiments we derived polyclonal fibroblasts cultures from wild-type, heterozygous, and homozygous mutant E9 embryos. Growth of the cells of each genotype was comparable in terms of viability when established and their growth rate at different densities and serum concentrations (data not shown). The effects of EGF stimulation of these cells on MAPK was assayed as a relatively simple measure of activation of the ras pathway. Phosphorylation of MAPK occurs in an EGF-stimulated, rasdependent manner (for review, see Marshall 1995) and can be monitored indirectly by the reduced mobility of the phosphorylated protein on SDS-PAGE gels. A pronounced mobility shift of MAPK was observed 5 min after EGF stimulation of wild-type or heterozygous fibroblasts but was substantially attenuated in all three Sos1-/- polyclonal cell lines examined (Fig. 5A). Two of the homozygous mutant cell lines showed a partial re- sponse, but the third line was completely unresponsive. The partial response seen in two of the lines was not improved significantly by use of increasing concentrations of EGF (Fig. 5B). A requirement for Sos 1 in cytokine signaling has been demonstrated previously only in insulin stimulated cells that highly overexpress a dominant negative Sos 1 protein (Sakaue et al. 1995). These findings demonstrated for the first time that Sosl has an important role in EGF-stimulated MAP kinase activation in fibroblasts under physiological conditions.

\section{Heterozygous mutation in Sos1 acts as a dominant enhancer of wa-2}

The role of Sos1 in the EGF signaling pathway was further explored by examining whether an interaction could be seen between Sos1 and EGFR mutations in vivo. For this analysis we chose mice that were homozygous for a weak allele of the EGFR (wa-2; Crew 1993; Luetteke et 

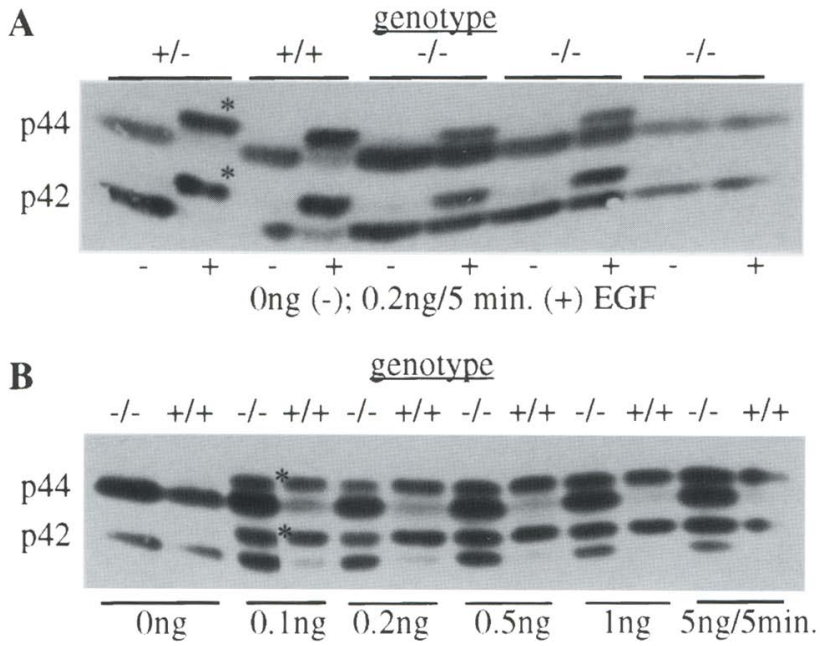

Figure 5. EGF-stimulated MAPK activation in primary fibroblasts. (A) Cells were derived from wild-type $(+1+1$, heterozygous $(+\mid-)$, or homozygous $(-1-)$ E9.0 embryos, as indicated. Stimulation of wild-type and heterozygous fibroblasts with EGF resulted in a marked reduction in the mobility of $\mathrm{p} 42$ and $\mathrm{p} 44$ MAPK $\left({ }^{*}\right)$, reflecting the phosphorylation and activation of these proteins. Each of three polyclonal Sos 1-/- fibroblast cell lines were substantially less responsive to EGF, with either partial responses (two cell lines) or no response (one cell line). $(B)$ One of the partially responsive lines shown in $A$ was tested at the indicated EGF concentrations. MAPK activation was not substantially improved by using higher concentrations of EGF.

al. 1994; Fowler et al. 1995). These mice have wavy hair and reduced perinatal viability but are generally viable and fertile. In contrast, null mutation in the EGFR results in embryonic or perinatal lethality depending on genetic background (Miettinen et al. 1995; Sibilia and Wagner 1995; Threadgill et al. 1995). The eyelids of $E G F R$ null mutant pups are invariably open at birth as a result of a delay in epithelial maturation (Miettinen et al. 1995; Sibilia and Wagner 1995). This phenotype is also observed sporadically in wa-2 mice (Butler and Robertson 1953). Perinatal viability and hair and eye defects therefore provided assays to test for enhancement of the wa-2 phenotype by loss of one copy of Sos1. In studies where doubly mutant animals are generated, if there is no interaction between the two mutations then the phenotype should be a summation of the individual phenotypes. Sos $1+1-$ mice are indistinguishable from wildtype animals. Therefore, if $w a-2$ and Sos 1 do not interact then we would expect wa-2/wa-2;Sos $1+1-$ mice to be identical in appearance to their wa-2/wa-2;Sos $1+/+$ littermates. If, however, there is an interaction between the two mutations we would expect that the phenotype of the wa-2/wa-2;Sos $1+/$ - animals to more closely resemble the EGFR null mutant animals.

In order to determine whether the Sos 1 mutation enhanced the penetrance of open eyelids in neonatal wa-2 mice, we intercrossed $w a-2 / w a-2 ; \operatorname{Sos} 1+1+$ and $w a-2 / w a-$ 2;Sos $1+/-$ mice. The resulting pups were labeled at birth and observed daily thereafter. Eight of the 64 resulting pups had one or both eyelids open at birth (Fig. 6A). Only 48 of the pups survived long enough to be genotyped and of these animals 14 were wa-2/wa-2;Sos $1+/-$ and 34 were $w a-2 / w a-2 ; \operatorname{Sos} 1+/+$. As equal numbers of each genotype were expected, this finding indicated that a heterozygous mutation in Sos 1 increased the lethality associated with the wa-2 mutation. This result was consistent with the high rate of neonatal mortality associated with an EGFR null mutation (Miettinen et al. 1995; Sibilia and Wagner 1995; Threadgill et al. 1995). Importantly, of the eight animals whose eyes were open at birth, seven were $w a-2 / w a-2 ; \operatorname{Sos} 1+/-$ and only one was $w a-2 / w a-2 ; \operatorname{Sos} 1+1+($ Table 2$)$. Therefore, reducing the dosage of Sos 1 by half also increased the penetrance of the eyelid phenotype of the hypomorphic wa-2 allele, toward that seen with null alleles of the EGFR.

Only two of the wa-2/wa-2;Sos $1+/$ - pups, whose eyelids were open at birth, survived to adulthood. Interestingly, one developed a unilateral corneal opacity and the other a unilateral micropthalmia. The adult eye phenotype was investigated in greater detail in the progeny of an intercross of homozygous $w a-2$ mice and mice heterozygous for wa-2 and Sos 1 mutations. This intercross allowed us to also further compare the effects of the $w a-2$ and Sos 1 mutations on viability as mice with four possible genotypes were expected in equal numbers. These genotypes and the actual numbers surviving to weaning are detailed in Table 2 . As before, a lower than expected number of pups was obtained in the wa-2/wa-2;Sos $1+1+$ group and even fewer in the $w a-2 / w a-2 ; \operatorname{Sos} 1+/-$ group. In addition, a strong interaction was seen between the

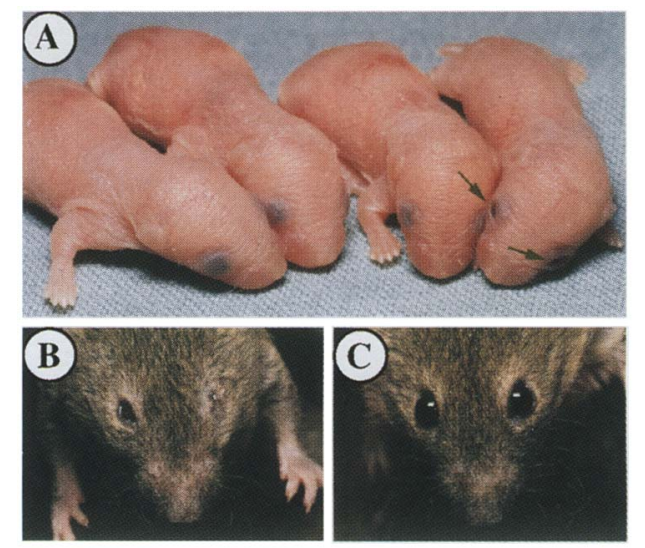

Figure 6. Interaction between Sos 1 and wa-2 mutations in neonates and adult mice. (A) Two-day-old pups from an intercross of wa-2,wa-2;Sos $1+1+$ and wa-2,wa-2;Sos $1+1-$ mice. The three mice on the left were $w a-2 / w a-2 ; \operatorname{Sos} 1+1+$, and their eyelids were still closed. The remaining mouse was wa-2/wa-2;Sos $1+1-$ and its eyelids (arrowed) were open at birth. $(B)$ Representative affected 6-week-old wa-2/wa-2; Sos $1+1$ - mouse with micro-ophthalmia and unilateral corneal opacity. The left eye was so severely affected that the eyelids were fused. (C) A wa-2/wa2 ; Sos $1+1+$ littermate. The eyes of all these animals appeared grossly normal to 9-12 months of age. The small white patches on each eye result from light reflected from their glistening surfaces. 
Table 2. Interaction between the wa-2 and Sos1 mutation results in neonatal and adult eye defects

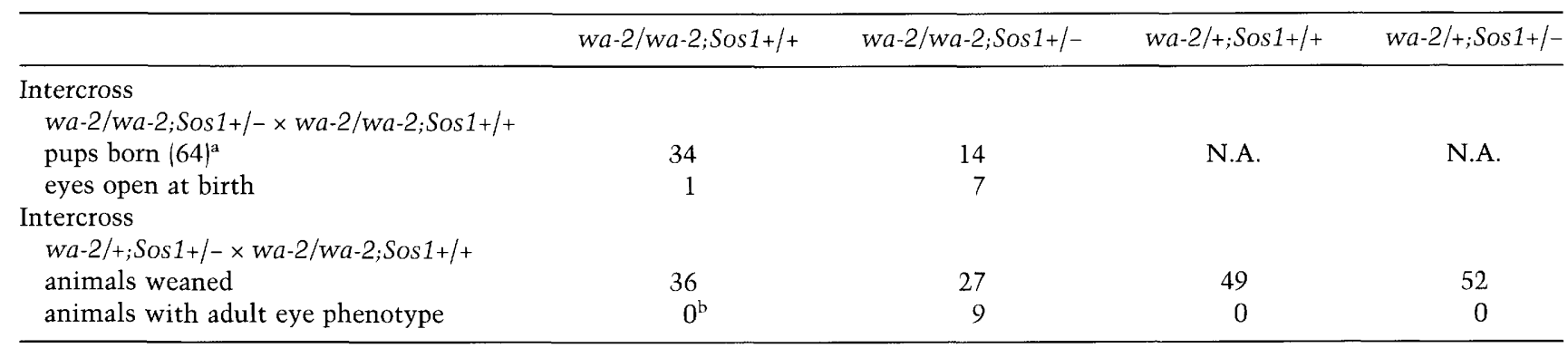

Two mating schemes were followed to investigate a possible interaction between the wa-2 mutation and Sos-1. In the first, animals of four possible genotypes should have been produced but fewer wa-2 homozygotes were obtained, particularly animals also heterozygous for Sos1. Nine of the wa-2/wa-2;Sos $1+/-$ mice developed a characteristic eye defect within their first few months (see text). The second breeding scheme should have produced equal numbers of Sos1 wild-type and Sos1 heterozygous pups in a homozygous wa-2 background. Eight of 64 pups had eyes open inappropriately at birth.

${ }^{a}$ Of these neonates 48 could be genotyped at 3 weeks of age, as the remainder died and were eaten.

bNo eye disease apparent as late as 9-11 months of age.

two mutations in the eyes of juvenile and adult mice. One-third of the wa-2/wa-2;Sos $1+1-$ mice developed a characteristic eye phenotype, involving uni- or bilateral corneal opacity, micro-ophthalmia, and crusting of the periorbital skin (Fig. 6B; Table 2). These defects were apparent either at weaning or had developed by 4 months of age. The phenotype was of variable expressivity, as approximately half of the affected animals showed a marked difference in the severity in each eye (e.g., see Fig. 6A). None of the animals with different genotypes, including wa-2/wa-2;Sos $1+1+$ littermates (Fig. 6C), had developed any eye abnormalities by 9-12 months of age (Table 2). Mild corneal opacity was seen sporadically in mice from our pedigree $w a-2$ colony, however, but was not grossly apparent in these mice until they were $>11$ months old. It is not clear why the wa-2/wa-2;Sos $1+/+$ and the pedigree $w a-2$ mice were not equivalently affected. Differences in the genetic backgrounds of these two groups (see Materials and Methods) may be responsible.

Histological analysis of the affected $w a-2 / w a-$ 2; Sos 1+1- mouse eyes revealed consistent defects involving the cornea, anterior chamber, ciliary body, and retina (Fig. 7A), whereas the eyes of $w a-2 / w a-2 ;$ Sos $1+/+$ mice were normal when sectioned (Fig. 7B). In contrast, the eyes from the sporadically affected founder colony of $w a-2$ mice resembled those from affected $w a-2 / w a-$ 2; Sos $1+1-$ mice (Fig. 7C). The cornea of affected wa-2/ wa-2;Sos1+/- mice was markedly thickened, showed signs of neovascularization, and contained fragments of pigmented tissue, possibly derived from the iris (Fig. 7, cf. D and E). The anterior chamber was hypotrophic and the lens and iris were attached to the cornea (Fig. 7, cf. D and E). The lens had disorganized fibers and was vacuolated (Fig. 7, cf. F and G) and in some of the affected mice the lens was reduced in size or rudimentary (data not shown). The ciliary body was either absent or rudimentary (Fig. 7 F,G) and the retina exhibited areas of focal disorganization (Fig. 7, cf. $\mathrm{H}$ and I). Six affected wa-2/wa-2;Sos $1 / \operatorname{Sos} 1+/$ - eyes were sectioned and all showed these features. These defects occurred at a simi- lar penetrance and closely resembled those observed in mice with a null mutation in TGF $\alpha$, an EGFR ligand (Luetteke e tal. 1993; Mann et al. 1993). Although only limited histological analysis of the eyes of EGFR null mice has been reported, the lens of neonates was also prolapsed into the anterior chamber and was adherent to the cornea and iris (Miettinen et al. 1995). Therefore, a heterozygous mutation in Sos 1 in a wa-2 background also resulted in an adult eye phenotype that resembled that seen in mice that were null for the EGFR or its ligand $(\mathrm{TGF} \alpha)$.

\section{Discussion}

A favored model for Sos action involves ligand-stimulated recruitment of a complex of Sos 1 and Grb2 from the cytosol to activated receptors where the Sos protein can then activate ras (for review, see Barsagi 1994). Although aspects of this model are appealing, it has been difficult to test the functional importance of Sos proteins in such signaling pathways. Two studies recently have contradicted the above model by demonstrating that the Grb2 binding site on Sos is dispensable both for signaling by the sevenless receptor in the Drosophila eye (Karlovich et al. 1995) and for ras activation in COS7 cells that overexpress Sos 1 (McCollam et al. 1995). These findings point to the need to complement previous biochemical studies with more functional analyses of the Sos proteins. The experiments described here provide the first evidence of a functional requirement for a mammalian Sos protein in growth factor signaling in vivo and provide a framework to extend this analysis to other signaling pathways.

\section{Loss of Sos 1 results in a severe embryonic phenotype}

Most, if not all, cells express and require ras proteins for their proliferation and/or differentiation (Marshall 1995). As a result the major ras-GEFs should also be widely expressed during development and in the adult. 
Figure 7. Histological analysis of eyes from affected wa-2, wa-2;Sos $1+1-$ mice. $(A)$ Section of the whole eye of an affected 1-month-old wa-2/wa-2;Sos1+/- mouse. The lens occupied the anterior chamber and ciliary body was absent $\left({ }^{\star}\right)$. The cellular architecture of the lens was disorganized and it was adherent to the iris and cornea. The space between the retina and retinal pigment epithelium (RPE) was probably the result of a fixation artefact. Boxed regions are represented in higher magnification images. $(B)$ The apparently normal eye of an wa-2/wa-2;Sos $1+1+$ agematched mouse. (C) A 12-month-old wa$2 /$ wa-2 mouse from the founder colony in which corneal opacity was first observed at 11 months. As noted in the wa-2/wa2; Sos $1+1-$ mice, adhesion of the iris to the cornea, disorganization of the anterior chamber, and absence of the ciliary body was apparent. $\{D\}$ Higher magnification of the section shown in $A$. The anterior
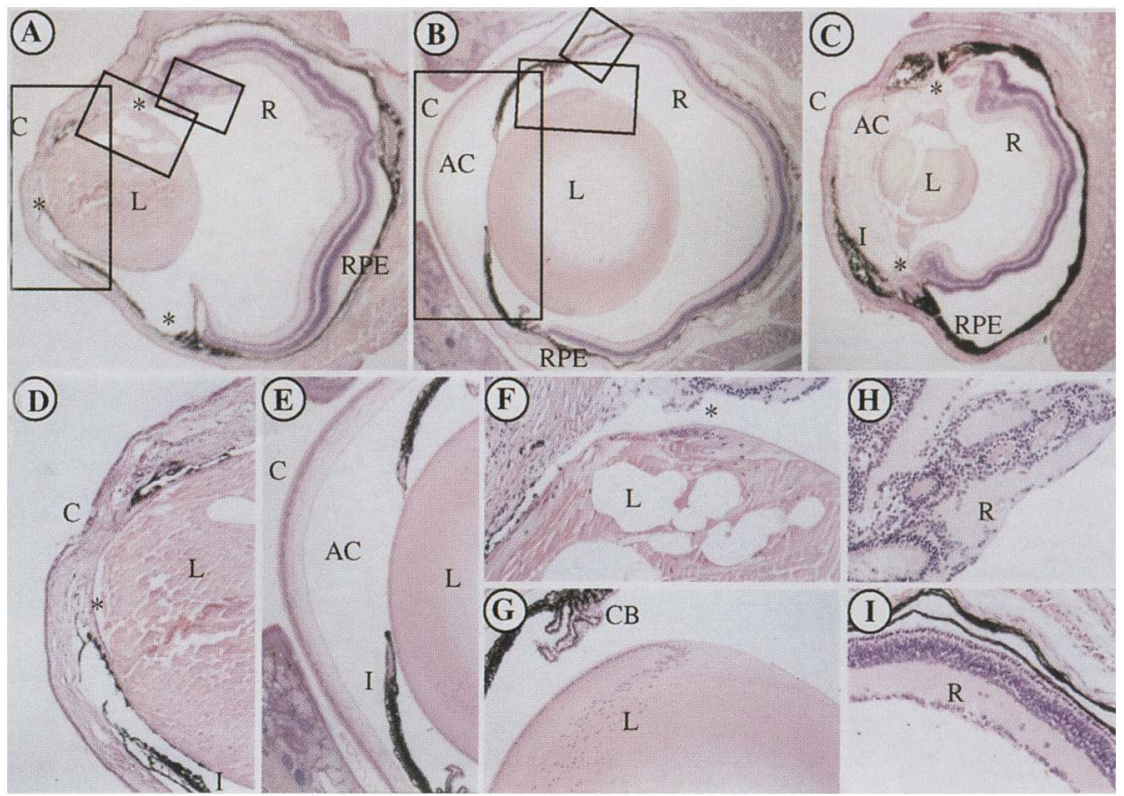
chamber, which is normally in the position indicated by the asterisk, was absent. $(E)$ Corresponding region from the wa-2,wa-2;Sos $1+/+$ littermate. $(F)$ Higher magnification of region in $A$, showing disordered lens fibers and vacuolated lens. The ciliary body, normally in the position indicated by the asterisk, was absent or rudimentary. (G) Higher magnification of the corresponding region of the section shown in $B$. (H) An area of focal disorganization of the retina, apparently a result of outgrowth and folding of the retina. (I) Corresponding region of the eye in section shown in $B$. $(\mathrm{R})$ retina; $(\mathrm{L})$ lens; $(\mathrm{C})$ cornea; $(\mathrm{CB})$ ciliary body; (RPE) retinal pigment epithelium; $(\mathrm{AC})$ anterior chamber; $(\mathrm{I})$ iris.

Incorporation of lac $Z$ in the targeting construct allowed examination of Sos 1 expression at a single-cell level in developing mice for the first time. Widespread $\beta$-galactosidase expression was observed, which, together with our Northern analysis of adult tissue, contrasts with the more restricted patterns of expression reported for other GEFs (for review, see Bowtell 1996a). These findings support the notion that Sosl is a major activator of ras in mice. Consistent with this view, homozygous mutation in Sos1 resulted in a range of embryonic defects that culminated in mid-gestational lethality. The relatively late lethality associated with the Sos1 mutation, however, contrasts with the embryonic lethality seen in $D$ Sos mutant flies (Simon et al. 1991; Bonfini et al. 1992). This difference may be attributable to the presence of only one Sos gene in Drosophila. Although we see no evidence of up-regulation of Sos2 in mutant mice, Sos2 is normally expressed quite widely and may partially compensate for the absence of Sos1. If so, the phenotype of the Sos 1-/- mice may be a consequence of developmental defects arising in tissues that do not express Sos2 and therefore lack both Sos1 and Sos2. Both Sos1 and Sos2 are expressed in the adult heart, as judged by Northern analysis. We are currently examining the expression of both genes at higher resolution in the developing heart.

The most prominent disorders seen in the Sos 1-/- embryos involved defects in the cardiovascular system and were manifest as defective myocardial development, cardiac and pericardial hypertrophy, and focal hemorrhage. Pale yolk sacs were commonly observed in mutant animals, and these may also reflect the underlying cardio- vascular disorder. Consistent with this view, a pale yolk

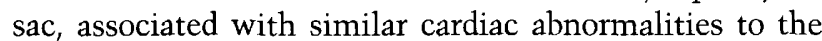
Sos $1-/-$ mice, was also seen at E10.5 in mice that are mutant for the transcription enhancer factor-1 (TEF-1) (Chen et al. 1994). It appears that a pale yolk sac may be a consequence of redistribution of red cells within the engorged vascular spaces and tissues of the failing embryo.

An alternative possibility, that the yolk sac phenotype in the Sos1-/- mice represents a failure in yolk sac hemopoiesis, appears unlikely for several reasons. Although Sos 1-/- embryos die in the early stages of hemopoietic development, we were able to find large numbers of nucleated red cells, which are typically yolk sac-derived (Wong et al. 1986), in mutant embryos. In addition, red cell formation by differentiated Sos1-/- ES cells appeared comparable to heterozygous and wild-type parental ES cells. The normal number of myeloid precursors that were found in Sos1-/- yolk sacs further indicated that early hemopoiesis is largely normal in Sos 1 mutant mice. Although yolk sacs from Sos1-/- mice were depleted of red cells, no other defect was apparent. Placental defects, involving the spongiotrophoblast cell layer, were reported in mice that were null for the EGFR (Sibilia and Wagner 1995; Threadgill et al. 1995). However, we saw no evidence of a similar defect in the Sos 1-/- mice or any other evidence of placental defects.

Mid-gestational lethality associated with cardiac failure has been seen in mice that are mutant for various genes, including TH, NF-1, TEF-1, Her2, Her4, and neuregulin (Moens et al. 1993; Chen et al. 1994; Jacks et al. 1994; Lee et al. 1995; Gassmann et al. 1995; Meyer and 
Birchmeier 1996; Zhou et al. 1995). Of these mutant animals, the TEF-1 mice most closely resemble the Sos 1-1embryos, both in terms of time of onset of the defect and the associated pale yolk sac. However, we did not observe the dilation of the forth ventricle of the brain seen in the TEF-1 mutant mice, which was believed to be a consequence of cardiac failure in these animals. Whether the resemblance between these mutants and the Sos 1 mutant embryos simply reflects the common features of cardiac failure of any cause or is a result of a more direct biochemical connection between Sosl and these proteins is unknown. However, given our demonstration that Sosl is required downstream of the EGFR, it is particularly noteworthy that defects in ventricular trabeculation are also seen when other EGFR or ligand gene family members are mutated (Her2, Her4, and neuregulin). These findings suggests that Sos1 may also function downstream of these proteins in a pathway essential for ventricular development.

An additional aspect of the Sos1-/- embryonic phenotype was hemorrhage. Extensive hemorrhage has been reported in embryos that are mutant for syk, platelet-derived growth factor (PDGF) B, or its $\beta$-receptor (Leveen et al. 1994; Soriano 1994; Cheng et al. 1995). The hemorrhage observed in the Sos1-/- embryos appeared to have a more focal distribution than in these other mutants. It is possible that the pattern seen in Sos $1-/-$ mice may represent an area of focal necrosis or developmental failure (e.g., see Wang et al. 1996), rather than generalized platelet or endothelial dysfunction. We believe that the Sos1 mutant embryos have other defects that indicate that the effects of loss of the Sos1 gene are quite pleotropic. Whether these changes are a secondary consequence of an earlier developmental failure or a direct result of loss of the Sosl protein is the subject of ongoing investigation in our laboratory and will be described in greater detail elsewhere.

The widespread pattern of Sos 1 expression and lethality and range of defects seen in the Sos1-/- embryos made it difficult to use homozygous mutant mice to identify the specific signaling pathways that required Sosl. In fact, pleotropic defects, often associated with early lethality, are common features of mutations in many signaling proteins. This outcome represents a challenge if such mutant animals are to be used to characterize the importance of widely used signal transduction molecules to specific signaling pathways. We sought to circumvent these problems in the Sos1-/mice by examining responses in isolated cells and by investigating a genetic interaction between Sos1 and a barely functional receptor allele (wa-2).

\section{Interaction of Sos1 and wa-2}

Introducing a heterozygous mutation in Sos 1 into a wa-2 background increased the penetrance of perinatal lethality, open eyelids at birth, and a distinctive adult eye phenotype. Each feature is associated with a null mutation in the EGFR and/or its ligand, TGF $\alpha$ (Luetteke et al. 1993; Mann et al. 1993; Miettinen et al. 1995; Sibilia and Wagner 1995; Berkowitz et al. 1996). Thus Sos1 acted as a dominant enhancer of $w a-2$, demonstrating a Sos 1 re- quirement for EGFR signaling. The mutation squint cataract $(s q)$ has been described, which, when present in a homozygous wa-2 background, results in lens prolapse and cataracts (Butler and Robertson 1953). Therefore, analogous to Sos 1, $s q$ acts as an enhancer of the wa-2 eye phenotype. As such it is possible that $s q$ represents an allele of Sos1. The gene for $s q$, however, has not been identified or its chromosomal position determined.

It is interesting that of the signaling pathways involving the EGFR, the eye was particularly sensitive to a reduction in the dosage of Sos1. The fact that wa-2 mice are occasionally born with open eyelids and adult mice develop eye defects at a low penetrance suggests that signaling by the wa-2 allele is barely adequate in the eye. This situation makes the eye an ideal site to observe the effects of reduced signaling by the EGFR as a consequence of halving the dosage of Sos1 or another component of the ras pathway. It is not clear, however, why other tissues such as the skin, which are mildly affected in wa-2 mice and severely affected in EGFR null mice, were not further affected by a reduction in the amount of Sos1. It may be that Sos2, or another GEF, can compensate for a heterozygous mutation in Sos1 in such tissues or that any enhancement of the phenotype in these sites was too subtle to be detected.

Our analysis adds to a growing literature that demonstrates that the EGFR signaling pathway plays an important role in the eye. The EGFR is normally expressed in the perioptic and intraoptic mesenchyme (Reneker et al. 1995), and it and TGF $\alpha$ are expressed in the advancing eyelid margins during development (Berkowitz et al. 1996). Ectopic expression of TGF $\alpha$ in the lens of transgenic mice, under the control of the $\alpha \mathrm{A}$-crystallin promoter, results in corneal opacity, cataracts, and microophthalmia as a consequence of inappropriate mesenchymal accumulation around the lens (Reneker et al 1995). These animals also display retinal disorganization. Overexpression of the EGFR in retinal precursor cells results in altered cell fate in the developing retina (Lillien 1995). The effects of TGF $\alpha$ and EGFR overexpression on the retina is of particular interest, as the retinas of wa-2/wa-2;Sos $1+/-$ mice also showed areas of focal disorganization. Consequently it would be interesting to examine more closely cell differentiation in the retinas of affected wa-2,wa-2;Sos $1+/$ - mice.

Mice that are mutant for more than one gene have been used previously to demonstrate an interaction between two proteins. Such interactions have been useful in demonstrating functional redundancy between related proteins, such as GAPl and NF1 (Henkemeyer et al. 1995). Alternatively, homozygous deletion of one protein has been used to demonstrate its requirement for signaling by another protein, for example the dependence of middle- $\mathrm{T}$ antigen on src for mammary tumor development (Guy et al. 1994). Our study is the first example in mice in which a heterozygous mutation in one component of signaling pathway has been shown to enhance the phenotype of weak mutation in another component of the ras pathway. This approach is identical to that used to initially clone D-Sos in Drosophila 
(Rogge et al. 1991; Bonfini et al. 1992; Simon et al. 1992). Heterozygous mutations in many of the other proteins in the Drosophila ras pathway, including D-ras, Drk (Grb2), and rolled (MAPK), also behave as enhancers of weak receptor alleles (for review, see Bowtell 1996b). Given this, and our findings with Sos1, it is likely that this approach could be applied to the analysis of other proteins in the mammalian ras pathway.

\section{Materials and methods}

Sos1 targeting vector and isolation of targeted ES cells and mice

Murine Sos1 genomic clones were isolated from a $\lambda$ UNI-ZAP 129Sv library (Stratagene) and the position of the $5^{\prime}$ coding exons determined using standard procedures (Sambrook et al. 1989). A 6-kb $B g I I I$ fragment was obtained by partial digest and subcloned into the BamHI site of pBSII (Stratagene). A PstI-BgIII fragment was subcloned into pALT (Promega) and a BamHI site introduced converting the sequence TAATGATGATGCTCT to TAATGAGGATCCTCT. This fragment was returned to the $6-\mathrm{kb} B g / I \mathrm{l}$ fragment and a 4.2-kb lacZ-neo (Friedrich and Soriano 1993) cassette was inserted into the $B a m H I$ site, in-frame with the coding region of Sos1, 44 amino acids carboxy-terminal to the Sos1 initiating methionine codon (Bowtell et al. 1992). The construct was linearized with NotI and electroporated into R1 ES cells (Nagy et al. 1993). Targeted ES cells were selected in G418 at $150 \mu \mathrm{g} / \mathrm{ml}$. DNA was obtained for Southern analysis of these clones using a guanidine $\mathrm{HCl}$ extraction procedure (Bowtell 1987). To identify targeted clones, filters were probed with a ${ }^{32} \mathrm{P}$-labeled genomic fragment (Probe A, Fig. 1B) outside the targeting construct. Targeted clones were expected to have a new band of $9.4 \mathrm{~kb}$, following digestion of clone DNA with Xhol. One of two G418 resistant clones obtained from the first screen had undergone a single homologous recombination event. Homozygous mutant ES cells were derived subsequently by selection of this clone in increasing concentrations of G418 (Mortensen et al. 1992). The genotype of resistant clones and their lack of expression of Sos1 was confirmed following adaptation to growth without embryonic feeder cells. Three homozygous clones were obtained and used for in vitro differentiation studies.

Chimeric mice were generated by microinjection of 12-15 Sos 1+/- ES cells per E3.5 day C57BL/6 $\times$ C57BL/10ScSn blastocyst or by aggregation of eight cells with E2.5 R.B Swiss morulae. Male chimeras were mated to C57BL/6J females. Southern blot analysis of tail DNA of pups was performed using standard procedures (Sambrook et al. 1989) and approximately half of the agouti pups were heterozygous for the Sos1 mutation. These mice were backcrossed with C57BL/6J males or females for further analysis. Chimeras that had a high rate of germ-line transmission were crossed to $129 \mathrm{~Sv}$ female mice to produce Sos $1+/$ - mice with a $129 \mathrm{~Sv}$ background. Heterozygous animals were intercrossed to produce homozygous mutant progeny. However, the presence of residual unrestricted DNA made it difficult to determine whether mice were homozygous mutant or heterozygous when using a probe to sequences outside the targeting construct (Probe A, Fig. 1B), as the wild-type allele ran at limit mobility. Therefore, DNA from F2 heterozygous intercross mice was analyzed using a second probe (Probe B, Fig. 1B), which hybridized with smaller fragments in a BgIII digest. Embryos from timed matings (noon on the day of vaginal plug is 0.5 days) were genotyped by carefully microdissecting yolk sacs free of all maternal components and then performing a PCR-based analysis with the primers represented in Figure 1B: (A) 5'-CATGCATGGTGTATGAGGCT-3';(B) 5'-GGCTGAGCTTGGCATAGCAT-3'; (C) 5'-CAG-
TATCGGCCTCAGGAAGA-3'. Yolk sacs were digested in $50 \mu \mathrm{l}$ of $1 \times$ PCR buffer (Promega) with $0.45 \%$ NP-40, $0.45 \%$ Tween 20 , proteinase $\mathrm{K}(100 \mu \mathrm{g} / \mathrm{ml})$ at $50^{\circ} \mathrm{C}$ for $30 \mathrm{~min}$, boiled for $5 \mathrm{~min}$, and then $2 \mu \mathrm{l}$ was subjected to PCR under the following conditions: All three primers were added simultaneously to the mix: (A) $0.25 \mu \mathrm{M}$; (B) $0.05 \mu \mathrm{M}_{\text {; }}$ (C) $0.2 \mu \mathrm{M}_{\text {; }} 1 \times$ PCR buffer, $2 \mathrm{mM} \mathrm{MgCl}_{2}, 100 \mu \mathrm{M} \mathrm{dNTP}$, 1.25 unit Taq (Promega). Denaturation for $94^{\circ} \mathrm{C}$ for $4 \mathrm{~min}$ followed by 30 cycles of $94^{\circ} \mathrm{C}$ for $1 \mathrm{~min}, 60^{\circ} \mathrm{C}$ for $1 \mathrm{~min}, 72^{\circ} \mathrm{C}$ for $1 \mathrm{~min}$, and final extension for $10 \mathrm{~min}$. Product A-C, wild-type allele: $200 \mathrm{bp}$, mutant allele too large to amplify efficiently; product $\mathrm{A}-\mathrm{B}$, mutant allele only: $400 \mathrm{bp}$. Western blots of embryonic tissues, lysed directly in SDS-sample buffer, were performed with a Sos1 antisera directed against the peptide LGKKSDHGNAFFPNSPSPFT and with an anti-cbl serum (R2), essentially as described previously (Bowtell and Langdon 1995). Poly(A) ${ }^{+}$RNA was isolated from tissues using an acid phenol method (Chomczynski and Sacchi 1987) and from ES cells, depleted of feeder cells, using proteinase $\mathrm{K}$ and SDS (Gonda et al. 1985). RNA was hybridized with Sos1- and Sos2-specific probes (Bowtell et al. 1992).

\section{Derivation of fibroblast cells lines and MAPK assay}

E9.0 embryos that were grossly normal were dissected free from maternal components. They were genotyped by PCR and the absence of Sosl protein was confirmed by Western blotting Embryos were homogenized and established in culture essentially as described previously (Todaro and Green 1963). Passage 20 cells were plated at $2 \times 10^{5}$ in $35-\mathrm{mm}$ dishes and starved in $0.2 \%$ serum containing media overnight. Cultures were stimulated with murine EGF at $0.2 \mathrm{ng} / \mathrm{ml}$ or as indicated, for $5 \mathrm{~min}$ The media was aspirated, the cells rinsed with ice-cold phosphate buffered saline, and then lysed in SDS-sample buffer. Lysates were separated on SDS-PAGE gels and Western blots were probed with antisera to $\mathrm{p} 42 / \mathrm{p} 44 \mathrm{MAP}$ kinase, as described previously (Bowtell and Langdon 1995).

\section{Assay of myeloid progenitors}

Cells harvested from individual yolk sacs were dispersed by agitation and gentle vortexing in $1 \mathrm{ml}$ of balanced salt solution. Yolk sac cells were assayed in a double-layer nutrient agar culture system (Bradley et al. 1978) for the presence of granulocytemacrophage lineage restricted progenitors stimulated by the combination of recombinant murine granulocyte macrophage colony-stimulating factor (GM-CSF) (Amgen, $20 \mathrm{ng} / \mathrm{ml}$ ) and partially purified pregnant mouse uterus extract as a source of M-CSF (Bradley et al. 1971). Colonies of at least 50 cells were scored after 14 days incubation.

\section{Histological analysis}

To stain for $\beta$-galactosidase activity embryos were fixed in $4 \%$ paraformaldehyde, $0.2 \%$ glutaraldehyde in ice-cold embryo buffer $\left(0.1 \mathrm{M}\right.$ phosphate at $\mathrm{pH} 7.3,200 \mu \mathrm{M} \mathrm{MgCl}_{2}, 5 \mathrm{~mm}$ EGTA) for $10 \mathrm{~min}$, rinsed in PBS twice, then washed $3 \times 20 \mathrm{~min}$ in wash buffer (1x embryo buffer with $0.01 \%$ sodium deoxycholate, $0.02 \% \mathrm{NP}-40$ ). Embryos were preincubated for $40 \mathrm{~min}$ in staining solution ( $1 \times$ wash buffer with $5 \mathrm{~mm}$ potassium ferricyanide, $5 \mathrm{~mm}$ potassium ferrocyanide) before the addition of X-gal $\{1$ $\mathrm{mg} / \mathrm{ml}$. The embryos were incubated overnight at $34^{\circ} \mathrm{C}$. For sectioning, embryos were dehydrated through an alcohol series and paraffin embedded. Embryos were genotyped using PCR analysis of yolk sacs. Embryos and juvenile and adult eyes were fixed in Bouin's solution $110 \%$ formaldehyde, $0.7 \%$ picric acid, $5 \%$ acetic acid) and processed for hematoxylin and eosin staining using standard procedures. Eye sections were obtained by first chilling the paraffin block on ice and then adding a drop of water to the cut surface to facilitate sectioning of the lens. 


\section{Mouse strains and crosses}

C57BL/6J and 129Sv mice were obtained from the Animal Resource Center, Murdoch Western Australia. Breeding pairs of B6C3-a/A-wa-2/wa-2 $v t / v t$ mice were derived from an intercross of mice originally obtained from the Jackson Laboratories (Bar Harbor, ME). These were intercrossed with $129 \mathrm{~Sv}$ background Sos $1+/-$ heterozygous mice to create $w a-2 /+$; Sos $1+/-$ animals. These animals were backcrossed to B6C $3-a / A-w a-2 /$ $w a-2 v t / v t$ mice to produce mice of four possible genotypes (see text). The distinctive wavy coat phenotype was used to distinguish wa-2 homozygotes from heterozygotes and PCR analysis used to identify mutant Sos1 mice. After weaning at three weeks, mice were inspected monthly for any eye abnormalities. For analysis of eyelid opening at birth $w a-2 / w a-2 ; \operatorname{Sos} 1+/-$ mice were crossed with littermate $w a-2 / w a-2 ; \operatorname{Sos} 1+1+$ mice and the resulting pups observed from birth for signs of premature eyelid opening. Animals were identified by marking with a felt-tip pen until their genotype could be assessed.

\section{Acknowledgments}

This work was supported by grants from Howard Hughes Medical Institute, Wellcome Trust, the Anti-Cancer Council of Victoria, the National Health and Medical Research Council of Australia and the Potter Foundation. D.D.L.B. is a Howard Hughes International Research Scholar and Wellcome Trust Senior Research Fellow in Medical Research in Australia. We are indebted to Christine Andrews, Elizabeth Watsone, Kylie Bond, and Fiona Christensen for excellent assistance with animals and to Lynn Troute, Deon Venter, and Manuella Palatsudes for help with histology. Debbie Donald was instrumental in the isolation of homozygous mutant Sos1 ES cells. We thank Ed Nice for his generous gifts of EGF and Patrick Tam for help with the interpretation of the Sos1 mutant embryos. We thank Doris Germain, Matthew O'Connell, Franchesca Walker, Jacqui Hung, Andrew Holloway, Yin Ling Hu, and Joseph Sambrook for comments on the manuscript.

The publication costs of this article were defrayed in part by payment of page charges. This article must therefore be hereby marked "advertisement" in accordance with 18 USC section 1734 solely to indicate this fact.

\section{References}

Barsagi, D. 1994. The Sos (Son of sevenless) protein. Trends Endocrinol. Metab. 5: 165-169.

Berkowitz, E.A., K.B. Seroogy, J.A. Schroeder, W.E. Russell, E.P. Evans, R.F. Riedel, H.K. Phillips, C.A. Harrison, D.C. Lee, and N.C. Luetteke. 1996. Characterization of the mouse transforming growth factor alpha gene-Its expression during eyelid development and in waved 1 tissue. Cell Growth Differ. 7: 1271-1282.

Bonfini, L., C.A. Karlovich, C. Dasgupta, and U. Baneriee. 1992. The Son of sevenless gene product: A putative activator of Ras. Science 255: 603-606.

Bowtell, D. and W.Y. Langdon. 1995. The protein product of the c-cbl oncogene rapidly complexes with the egf receptor and is tyrosine phosphorylated following egf stimulation. Oncogene 11: 1561-1567.

Bowtell, D., P. Fu, M. Simon, and P. Senior. 1992. Identification of murine homologues of the Drosophila son of sevenless gene: Potential activators of ras. Proc. Natl. Acad. Sci. 89: 6511-6515.

Bowtell, D.D. 1987. Rapid isolation of eukaryotic DNA. Anal. Biochem. 162: 463-465.
Bowtell, D.D.L. 1996a. Linking the cell surface with ras: Son of sevenless guanine nucleotide exchange factors. Curr. Opin. Endocrinol. Diabetes 3: 388-396.

- 1996b. Genetics of ras signaling in Drosophila. In Regulation of the Ras signaling network (ed. H. Maruta and A. Burgess). R.G. Lande, Austin, TX.

Bradley, T.R., E.R. Stanley, and M.A. Sumner. 1971. Factors from mouse tissues stimulating colony growth of mouse bone marrow cells in vitro. Aust. J. Exp. Biol. Med. Sci. 49: 595-603.

Bradley, T.R., G.S. Hodgson, and M. Rosendaal. 1978. The effect of oxygen tension on haemopoietic and fibroblast cell proliferation in vitro. J. Cell. Physiol. 97: 517-522.

Buday, L. and J. Downward. 1993. Epidermal growth factor regulates $\mathrm{p} 21$ ras through the formation of a complex of receptor, Grb2 adapter protein, and Sos nucleotide exchange factor. Cell 73: 611-620.

Butler, L. and D.A. Robertson. 1953. A new eye abnormality in the house mouse. J. Hered. 44: 13-16.

Chardin, P., J.H. Camoinis, N.W. Gale, L. van Aelst, J. Schlessinger, M.H. Wigler, and D. Bar-Sagi. 1993. Human Sos1: A guanine nucleotide exchange factor for Ras that binds to GRB2. Science 260: 1338-1343.

Chen, Z., G.A. Friedrich, and P. Soriano. 1994. Transcriptional enhancer factor 1 disruption by a retroviral gene trap leads to heart defects and embryonic lethality in mice. Genes \& Dev. 8: 2293-2301.

Cheng, A.M., B. Rowley, W. Pao, A Hayday, J.B. Bolen, and T. Pawson. 1995. Syk tyrosine kinase required for mouse viability and B-cell development. Nature 378: 303-306.

Chomczynski, P. and N. Sacchi. 1987. Single-step method of RNA isolation by acid guanidinium thiocyanate-phenolchloroform extraction. Anal. Biochem. 162: 156-159.

Crew, F.A.E. 1993. Waved: An autosomal recessive coat form character in the mouse. J. Genet. 27: 95-96.

Doyle, H.J. and J.M. Bishop. 1993. Torso, a receptor tyrosine kinase required for embryonic pattern formation, shares substrates with the sevenless and EGF-R pathways in Drosophila. Genes \& Dev. 7: 633-646.

Egan, S.E., B.W. Giddings, M.W. Brooks, L. Buday, A.M. Sizeland, and R.A. Weinberg. 1993. Association of Sos Ras exchange protein with Grb2 is implicated in tyrosine kinase signal transduction and transformation. Nature 363: 45-51.

Fowler, K.J., F. Walker, W. Alexander, M.L. Hibbs, E.C. Nice, R.M. Bohmer, G.B. Mann, C. Thumwood, R. Maglitto, J.A. Danks, R. Chetty, A.W. Burgess, and A.R. Dunn. 1995. A mutation in the epidermal growth factor receptor in waved-2 mice has a profound effect on receptor biochemistry that results in impaired lactation. Proc. Natl. Acad. Sci. 92: 1465-1469.

Friedrich, G. and P. Soriano. 1993. Insertional mutagenesis by retroviruses and promoter traps in embryonic stem cells. Methods Enzymol. 225: 681-701.

Gassmann, M., F. Casagranda, D. Orioli, H. Simon, C. Lai, R. Klein, and G. Lemke. 1995. Aberrant neural and cardiac development in mice lacking the erbb4 neuregulin receptor. Nature 378: 390-394.

Gonda, T.J., N.M. Gough, A.R. Dunn, and J. de Blaquiere. 1985. Nucleotide sequence of cDNA clones of the murine myb proto-oncogene. EMBO J. 4: 2003-2008.

Guy, C.T., S.K. Muthuswamy, R.D. Cardiff, P. Soriano, and W.J. Muller. 1994. Activation of the c-src tyrosine kinase is required for the induction of mammary tumors in transgenic mice. Genes \& Dev. 8: 23-32.

Henkemeyer, M., D.J. Rossi, D.P. Holmyard, M.C. Puri, G. Mbamalu, K.. Harpal, T.S. Shih, T. Jacks, and T. Pawson. 1995. Vascular system defects and neuronal apoptosis in mice lacking ras GTPase-activating protein. Nature 377: 695-701. 
Jacks, T., T.S. Shih, E.M. Schmitt, R.T. Bronson, A. Bernards, and R.A. Weinberg. 1994. Tumour predisposition in mice heterozygous for a targeted mutation in Nfl. Nature Genet. 7: 353-361.

Karlovich, C.A., L. Bonfini, L. McCollam, R.D. Rogge, A. Daga, M.P. Czech, and U. Banerjee. 1995. In vivo functional analysis of the ras exchange factor son of sevenless. Science 268: $576-579$.

Lee, K.F., H. Simon, H. Chen, B. Bates, M.C. Hung, and C. Hauser. 1995. Requirement for neuregulin receptor erbb2 in neural and cardiac development. Nature 378: 394-398.

Leveen, P., M. Pekny, S. Gebre-Medhin, B. Swolin, E. Larsson, and C. Besholtz. 1994. Mice deficient for PDGF B show renal, cardiovascular, and hematological abnormalities. Genes \& Dev. 8: 1875-1887.

Lillien, L. 1995. Chavger in retinal cell fate induced by overexpression of EGF receptor. Nature 377: 158-162.

Liu, B.X., W. Wei, and D. Broek. 1993. The catalytic domain of the mouse sosl gene product activates Ras proteins in vivo and in vitro. Oncogene 8: 3081-3084.

Luetteke, N.C., T.H. Qiu, R.L. Peiffer, P. Oliver, O. Smithies, and D.C. Lee. 1993. TGF alpha deficiency results in hair follicle and eye abnormalities in targeted and waved-1 mice. Cell 73: 263-278.

Luetteke, N.C., H.K. Phillips, T.H. Qiu, N.G. Copeland, H.S. Earp, N.A. Jenkins, and D.C. Lee. 1994. The mouse waved-2 phenotype results from a point mutation in the egf receptor tyrosine kinase. Genes \& Dev. 8: 399-413.

Mann, G.B., K.J. Fowler, A. Gabriel, E.C. Nice, R.L. Williams, and A.R. Dunn. 1993. Mice with a null mutation of the TGF alpha gene have abnormal skin architecture, wavy hair, and curly whiskers and often develop corneal inflammation. Cell 73: 249-261.

Marshall, C. 1995. The ras/raf/ERK pathway. In Guidebook to the small GTPases, 1st edition. (ed. M. Zerial and L.A. Huber). Oxford University Press, Oxford, UK.

McCollam, L., L. Bonfini, C.A. Karlovich, B.R. Conway, L.M. Kozma, U. Banerjee, and M.P. Czech. 1995. Functional roles for the pleckstrin and $\mathrm{dbl}$ homology regions in the ras exchange factor Son-of-sevenless. J. Biochem. 270: 15954-15957.

Meyer, D. and C. Birchmeier. 1995. Multiple essential functions of neuregulin in development. Nature 378: 386-390.

Miettinen, P.J., J.E. Berger, J. Meneses, Y. Phung, R.A. Pedersen, Z. Werb, and R. Derynck. 1995. Epithelial immaturity and multiorgan failure in mice lacking epidermal growth factor receptor. Nature 376: 337-341.

Moens, C.B., B.R. Stanton, L.F. Parada, and J. Rossant. 1993. Defects in heart and lung development in compound heterozygotes for two different targeted mutations at the N-myc locus. Development 119: 485-499.

Mortensen, R.M., D.A. Conner, S. Chao, A.A. Geisterfer-Lowrance, and J.G. Seidmann. 1992. Production of homozygous mutant ES cells with a single targeting construct. Mol. Cell. Biol. 12: 2391-2395.

Nagy, A., J. Rossant, R. Nagy, W. Abramownewerly, and J.C. Roder. 1993. Derivation of completely cell culture-derived mice from early-passage embryonic stem cells. Proc. Natl. Acad. Sci. 90: 8424-8428.

Nakanishi, H., S. Orita, K. Kaibuchi, K. Miura, H. Miki, T. Takenawa, and Y. Takai. 1994. Kinetic properties of Ash/ Grb2-interacting GDP/GTP exchange protein. Biochem. Biophys. Res. Commun. 198: 1255-1261.

Porfiri, E., T. Evans, P. Chardin, and J.F. Hancock. 1994. Prenylation of Ras proteins is required for efficient hSOS1promoted guanine nucleotide exchange. (Erraturn) J. Biol. Chem. 269: 22672-22677.
Reneker, L.W., D.W. Silversides, K. Patel, and P.A. Overbeek. 1995. TGF alpha can act as a chemoattractant to periopic mesenchymal cells in developing mouse eyes. Development 121: 1669-1680.

Rogge, R.D., C.A. Karlovich, and U. Banerjee. 1991. Genetic dissection of a neurodevelopmental pathway: Son of sevenless functions downstream of the sevenless and EGF receptor tyrosine kinases. Cell 64: 39-48.

Rossant, J. 1993. Gene targeting: A practical approach, fed. D. Rickwood and B.D. Hames). IRL Press, Oxford, UK.

Rozakis-Adcock, M., R. Fernley, J. Wade, T. Pawson, and D. Bowtell. 1993. The SH2 and SH3 domains of mammalian Grb2 couple the EGF receptor to the Ras activator mSosI. Nature 363: 83-85.

Sakaue, M., D. Bowtell, and M. Kasuga. 1995. A dominant-negative mutant of mSOS1 inhibits insulin-induced Ras activation and reveals Ras-dependent and -independent insulin signaling pathways. Mol. Cell. Biol. 15: 379-388.

Sambrook, J., E.F. Fritsch, and T. Maniatis. 1989. Molecular cloning: A laboratory manual, 2nd ed. Cold Spring Harbor Laboratory Press, Cold Spring Harbor, NY.

Sibilia, M. and E.F. Wagner. 1995. Strain-dependent epithelial defects in mice lacking the EGF receptor. Science 269: 234-238.

Simon, M.A., D.D.L. Bowtell, G.S. Dodson, T.R. Laverty, and G.M. Rubin. 1991. Ras1 and a putative guanine nucleotide exchange factor perform crucial steps in signaling by the sevenless protein tyrosine kinase. Cell 67: 701-716.

Simon, M.A., R.W. Carthew, M.E. Fortini, U. Gaul, G. Mardon, and G.M. Rubin. 1992. Signal transduction pathway initiated by activation of the sevenless tyrosine kinase receptor. Cold Spring Harbor Symp. Quant. Biol. 57: 375-380.

Soriano, P. 1994. Abnormal kidney development and hematological disorders in PDGF beta-erceptor mutant mice. Genes \& Dev. 8: 1888-1896.

Threadgill, D.W., A.A. Dlogosz, L.A. Hansen, T. Tennenbaum, U. Lichti, D. Yee, C. LaMantia, T. Mourton, K. Herrup, R.C. Harris, et al. 1995. Targeted disruption of mouse EGF receptor: Effect of genetic background on mutant phenotype. Science 269: 230-234.

Todaro, G.J. and H. Green. 1963. Quantitative studies of the growth fo mouse embryo cells in culture and their development into established lines. J. Cell Biol 17: 299-313.

Wang, Q., T. Stacy, M. Binder, M. Marinpadilla, A.H. Sharpe, and N.A. Speck. 1996. Disruption of the cbfa2 gene causes necrosis and hemorraging in the central nervous system and blocks definitive hematopoiesis. Proc. Natl. Acad. Sci. 93: 3444-3449.

Wang, W., E.M.C. Fischer, Q. Jia, J.M. Dunn, E. Porfiri, J. Downward, and S.E. Egan. 1995. The Grb2 binding domain of $\mathrm{mSos} 1$ is not required for downstream signal transduction. Nature Genet. 10: 294-300.

Webb, G.C., N.A. Jenkins, D.A. Largaespada, N.G. Copeland, C.S. Fernandez, and D.D. Bowtell. 1993. Mammalian homologues of the Drosophila Son of sevenless gene map to murine chromosomes 17 and 12 and to human chromosomes 2 and 14, resepectively. Genomics 18: 14-19.

Wong, P.M., S.W. Chung, D.H. Chui, and C.J. Eaves. 1986. Properties of the earliest clonogenic hemopoietic precursors to appear in the developing murine yolk sac. Proc. Natl. Acad. Sci. 83: 3851-3854.

Zhou, Q.Y., C.J. Quaife, and R.D. Palmiter. 1995. Targeted disruption of the tyrosine hydroxylase gene reveals that catecholamines are required fro mouse fetal development. $\mathrm{Na}$ ture 374: 640-643. 


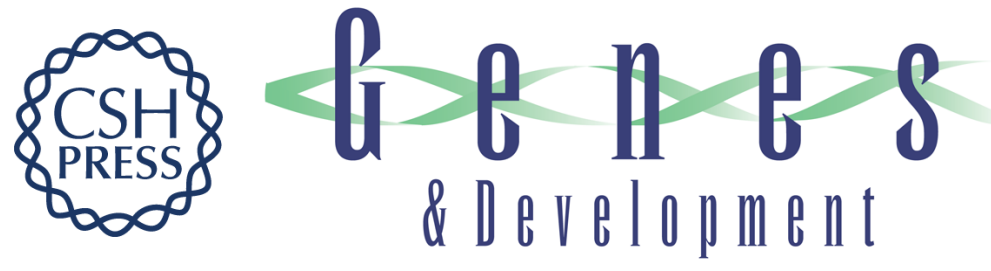

\section{Mutation in Sos1 dominantly enhances a weak allele of the EGFR, demonstrating a requirement for Sos1 in EGFR signaling and development.}

D Z Wang, V E Hammond, H E Abud, et al.

Genes Dev. 1997, 11:

Access the most recent version at doi:10.1101/gad.11.3.309

References This article cites 56 articles, 23 of which can be accessed free at: http://genesdev.cshlp.org/content/11/3/309.full.html\#ref-list-1

License

Email Alerting Service

Receive free email alerts when new articles cite this article - sign up in the box at the top right corner of the article or click here.

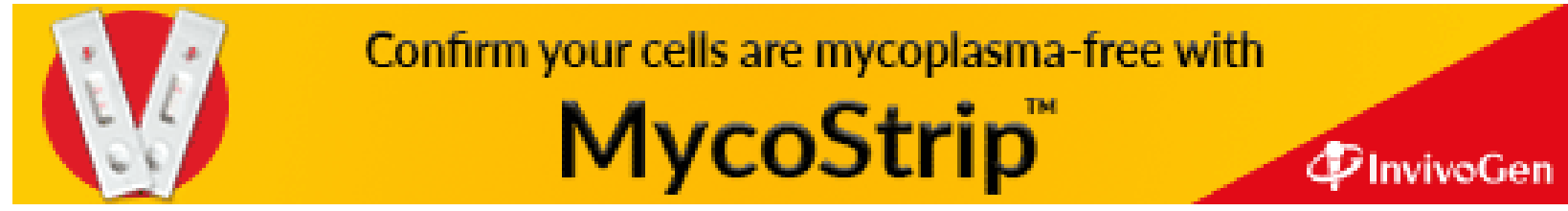

